


\section{Tracking Algal Blooms}

The same imaging capabilities that enable Landsat to tease out damage to the leaves of hemlock and maple trees can detect the chlorophyll of algae in bodies of water. These capabilities make Landsat a useful tool for tracking blooms of harmful cyanobacteria in Vermont's lakes and rivers. Such blooms pose a threat to aquatic ecosystems and to human health. Landsat can capture imagery of these blooms from more than 400 miles above the surface. Combining this imagery

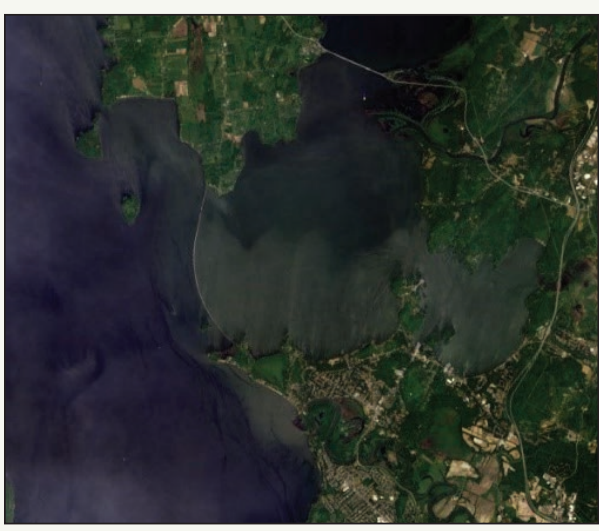
with on-the-ground survey data - as researchers did for a 2020 study on cyanobacteria distribution in Lake Champlain - can help map the location and frequency of blooms and inform decisions on how to mitigate the effects (Isenstein and others, 2020).

Landsat 8 image of Burlington, Vermont, and Lake Champlain, captured on June 1, 2013. The image shows swirls of cloudy green algae in the lake. Landsat imagery is useful in tracking algal blooms across the United States, including in Vermont.

\section{Vermont Agriculture and Land Use}

The multi-agency partnership known as the Lake Champlain Basin Program (LCBP) has used Landsat data to map and monitor the watershed. To help assess changes and trends in land use across the basin (Troy and others, 2007), the program used modified data from the National Land Cover Database (NLCD), a Landsat-based mapping project that assigns a land-cover class (pasture, developed, cropland, deciduous forest, and the like) to each 30 - by 30 -meter plot of ground in the Nation. The U.S. Department of Agriculture (USDA) also leans on Landsat imagery to help build its National Agricultural Statistics Service (NASS) Cropland Data Layer, an interactive geographic information system tool that shows the crops grown annually in every U.S. State.

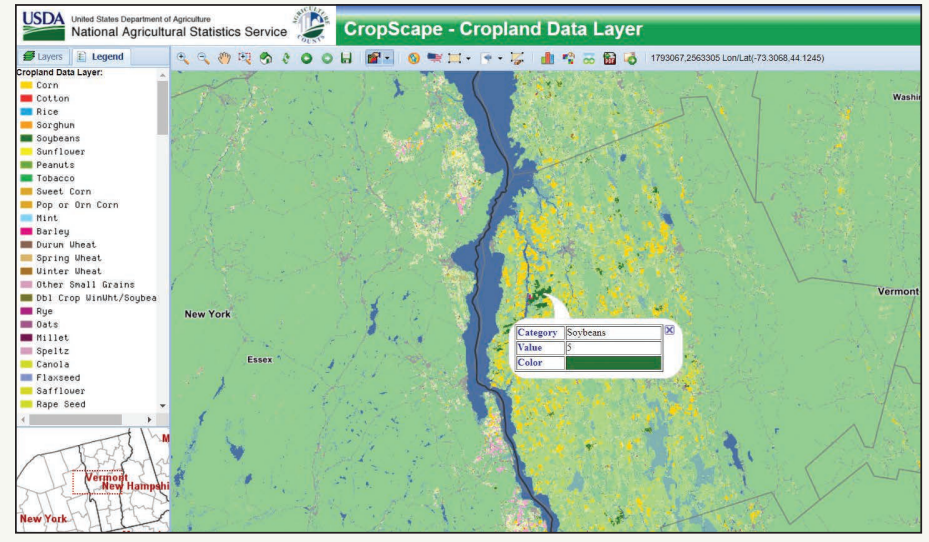

Screenshot of
USDA NASS
CropScape tool.
NASS uses Landsat
data to map the
crops grown in the
United States year
after year, which
can help identify
trends.

\section{References Cited}

Isenstein, E.M., Kim, D., and Park, M.-H., 2020, Modeling for multi-temporal cyanobacterial bloom dominance and distributions using Landsat imagery: Ecological Informatics, v. 59. [Also available at https://doi.org/10.1016/j. ecoinf.2020.101119.]

Jones, K., 2018, 2017 benchmark report-Tourism in Vermont: Vermont Department of Tourism and Marketing, $20 \mathrm{p}$., accessed May 28, 2021, at https://accd.vermont.gov/sites/accdnew/files/documents/VDTM/BenchmarkStudy/VDTMResearch-2017BenchmarkStudyFullReport.pdf.

Nevins, M.T., D'Amato, A.W., and Foster, J.R., 2021, Future forest composition under a changing climate and adaptive forest management in southeastern Vermont, USA: Forest Ecology and Management, v. 479. [Also available at https://doi.org/10.1016/j.foreco.2020.118527.

Straub, C.L., Koontz, S.R., and Loomis, J.B., 2019, Economic valuation of Landsat imagery: U.S. Geological Survey Open-File Report 2019-1112, 13 p. [Also available at https://doi.org/10.3133/ofr20191112.]

Troy, A., Wang, D., Capen, D., O’Neil Dunne, J., and MacFaden, S., 2007, Updating the Lake Champlain Basin land use data to improve prediction of phosphorus loading: Lake Champlain Basin Program, Technical Report 54, accessed May 28, 2021, at http://www.lcbp.org/techreportPDF/54_LULC-Phosphorus_2007.pdf.

University of Arkansas System, 2021, Vermont economic contribution and impact research: University of Arkansas System Division of Agriculture Research \& Extension web page, accessed May 28, 2021, at https://economic-impactof-ag.uark.edu/vermont/.

Vogelmann, J.E., and Rock, B.N., 1988, Assessing forest damage in high-elevation coniferous forests in Vermont and New Hampshire using thematic mapper data: Remote Sensing of Environment, v. 24, no. 2, p. 227-246. [Also available at https://doi.org/10.1016/0034-4257(88)90027-2.]

\section{Landsat-Critical Information Infrastructure for the Nation}

Landsat is the most widely used land remote sensing data source within Federal civilian agencies. Local, State, Tribal, and Federal agencies use Landsat to monitor and forecast a wide range of land surface phenomena. Information from Landsat contributes to day-to-day decisions on land, water, and resource use that protect life and property; safeguard the environment; advance science, technology, and education; support climate change resiliency; and grow the U.S. economy. Landsat's imagery provides a landscape-level view of land surface, inland lake, and coastal processes, both natural and human-induced. Landsat enables us to better understand the scope, nature, and speed of change to the natural and built environment.

Businesses draw upon Landsat data to provide customer-specific applications to improve logistics, resource allocation, and investment decisions. Commercial space-imaging firms leverage Landsat data to refine product offerings and support new information services. A 2017 USGS study determined the total annual economic benefit of Landsat data in the United States to be \$2.06 billion, far surpassing its development and operating costs (Straub and others, 2019).

Landsat 8 and Landsat 9 provide 8-day repeat coverage of the Earth's land surfaces. The National Aeronautics and Space Administration (NASA) and the USGS are currently reviewing the findings from a joint Architecture Study Team, which will inform the design and implementation approach for Landsat Next, the follow-on mission to Landsat 9. Landsat 9 and its successors are planned to provide a sustainable, space-based system to extend the 50-year Landsat series of high-quality global land imaging measurements - the world's longest time series of the Earth's land surface.

The long-term availability of consistent and accurate Landsat data, combined with a no-cost data policy, allows users to analyze extensive geographic areas and to better understand and manage long-term trends in land surface change. New cloud computing and data analytics technologies use Landsat data in a wide range of decision-support tools for Government and industry. Much like global positioning system and weather data, Landsat data are used every day to help us better understand our dynamic planet.

For additional information on Landsat, please contact: Program Coordinator USGS National Land Imaging Program 12201 Sunrise Valley Drive

Reston, VA 20192

703-648-5953

SSN 2327-6916 (print) ISSN 2327-6932 (online) https://doi.org/10.3133/fs20213038 